\title{
Surface ozone and its precursors at Summit, Greenland: comparison between observations and model simulations
}

\author{
Yaoxian Huang $^{1, a}$, Shiliang Wu ${ }^{1,2,3}$, Louisa J. Kramer ${ }^{1,2, b}$, Detlev Helmig ${ }^{4}$, and Richard E. Honrath ${ }^{1,2, \dagger}$ \\ ${ }^{1}$ Department of Geological and Mining Engineering and Sciences, Michigan Technological University, \\ Houghton, Michigan, USA \\ ${ }^{2}$ Atmospheric Sciences Program, Michigan Technological University, Houghton, Michigan, USA \\ ${ }^{3}$ College of Environmental Science and Engineering, Ocean University of China, Qingdao, China \\ ${ }^{4}$ Institute of Arctic and Alpine Research, University of Colorado, Boulder, Colorado, USA \\ a now at: Department of Climate and Space Sciences and Engineering, University of Michigan, \\ Ann Arbor, Michigan, USA \\ ${ }^{b}$ now at: School of Geography, Earth and Environmental Sciences, University of Birmingham, \\ Birmingham, UK \\ $\dagger$ deceased
}

Correspondence to: ShiliangWu (slwu@mtu.edu) and Yaoxian Huang (yaoxianh@mtu.edu)

Received: 15 May 2017 - Discussion started: 12 July 2017

Revised: 26 October 2017 - Accepted: 2 November 2017 - Published: 8 December 2017

\begin{abstract}
Recent studies have shown significant challenges for atmospheric models to simulate tropospheric ozone $\left(\mathrm{O}_{3}\right)$ and its precursors in the Arctic. In this study, ground-based data were combined with a global 3-D chemical transport model (GEOS-Chem) to examine the abundance and seasonal variations of $\mathrm{O}_{3}$ and its precursors at Summit, Greenland $\left(72.34^{\circ} \mathrm{N}, 38.29^{\circ} \mathrm{W} ; 3212 \mathrm{~m}\right.$ a.s.1.). Model simulations for atmospheric nitrogen oxides $\left(\mathrm{NO}_{x}\right)$, peroxyacetyl nitrate (PAN), ethane $\left(\mathrm{C}_{2} \mathrm{H}_{6}\right)$, propane $\left(\mathrm{C}_{3} \mathrm{H}_{8}\right)$, carbon monoxide (CO), and $\mathrm{O}_{3}$ for the period July 2008-June 2010 were compared with observations. The model performed well in simulating certain species (such as $\mathrm{CO}$ and $\mathrm{C}_{3} \mathrm{H}_{8}$ ), but some significant discrepancies were identified for other species and further investigated. The model generally underestimated $\mathrm{NO}_{x}$ and PAN (by $\sim 50$ and $30 \%$, respectively) for MarchJune. Likely contributing factors to the low bias include missing $\mathrm{NO}_{x}$ and PAN emissions from snowpack chemistry in the model. At the same time, the model overestimated $\mathrm{NO}_{x}$ mixing ratios by more than a factor of 2 in wintertime, with episodic $\mathrm{NO}_{x}$ mixing ratios up to 15 times higher than the typical $\mathrm{NO}_{x}$ levels at Summit. Further investigation showed that these simulated episodic $\mathrm{NO}_{x}$ spikes were always associated with transport events from Europe, but the exact cause remained unclear. The model systematically overesti-
\end{abstract}

mated $\mathrm{C}_{2} \mathrm{H}_{6}$ mixing ratios by approximately $20 \%$ relative to observations. This discrepancy can be resolved by decreasing anthropogenic $\mathrm{C}_{2} \mathrm{H}_{6}$ emissions over Asia and the US by $\sim 20 \%$, from 5.4 to $4.4 \mathrm{Tg}_{\text {year }}{ }^{-1}$. GEOS-Chem was able to reproduce the seasonal variability of $\mathrm{O}_{3}$ and its spring maximum. However, compared with observations, it underestimated surface $\mathrm{O}_{3}$ by approximately $13 \%$ (6.5 ppbv) from April to July. This low bias appeared to be driven by several factors including missing snowpack emissions of $\mathrm{NO}_{x}$ and nitrous acid in the model, the weak simulated stratosphereto-troposphere exchange flux of $\mathrm{O}_{3}$ over the summit, and the coarse model resolution.

\section{Introduction}

Tropospheric ozone $\left(\mathrm{O}_{3}\right)$ and its precursors, including nitrogen oxides $\left(\mathrm{NO}_{x}=\mathrm{NO}+\mathrm{NO}_{2}\right)$, carbon monoxide $(\mathrm{CO})$, and volatile organic compounds (VOCs, such as ethane and propane), are important atmospheric species affecting both air quality and climate (e.g., Jacob et al., 1992; Fiore et al., 2002; Unger et al., 2006; Hollaway et al., 2012). Tropospheric $\mathrm{O}_{3}$ is mainly produced through the photochemical oxidation of $\mathrm{CO}$ and VOCs in the presence of $\mathrm{NO}_{x}$, with an 
additional contribution by transport from the stratosphere. Its major sinks include chemical reactions and dry deposition. As a reservoir species for $\mathrm{NO}_{x}$, peroxyacetyl nitrate (PAN) also plays an important role in atmospheric chemistry. PAN, $\mathrm{O}_{3}$, and some of their precursors have relatively long lifetimes in the atmosphere, enabling them to be transported long distances to remote regions such as the Arctic.

Recent studies have shown some significant challenges for atmospheric chemical transport models to simulate $\mathrm{O}_{3}$ and its precursors in the Arctic (e.g., Shindell et al., 2008; Alvarado et al., 2010; Walker et al., 2012; Wespes et al., 2012; Fischer et al., 2014; Monks et al., 2015), but the causes remain unclear. In the multi-model assessment by Shindell et al. (2008), more than a dozen models all showed systematic and persistent underestimation of $\mathrm{O}_{3}$ at the GEOSummit station in Greenland (hereafter referred to as Summit). Alvarado et al. (2010) used $\mathrm{NO}_{x}$ and PAN measurements from the ARCTAS (Arctic Research of the Composition of the Troposphere from Aircraft and Satellites) mission in the summer to compare with model simulations. They found that model-simulated $\mathrm{NO}_{x}$ mixing ratios were higher than observations, while PAN mixing ratios were lower than the observations in fresh boreal fire plumes. In terms of global PAN simulations, Fischer et al. (2014) directly partitioned $40 \%$ of $\mathrm{NO}_{x}$ emissions from wildfires to PAN formation, which improved the agreement between the model and observations. However, the model still underestimated PAN surface mixing ratios during springtime in the Arctic. Walker et al. (2012) reported that model-simulated $\mathrm{O}_{3}$ mixing ratios were biased low when compared with balloon data during summertime from two high-latitude sites at Eureka $\left(80^{\circ} \mathrm{N}\right.$, $\left.86^{\circ} \mathrm{W}\right)$ and $\mathrm{Ny}$-Ålesund $\left(79^{\circ} \mathrm{N}, 12^{\circ} \mathrm{E}\right)$. Wespes et al. (2012) also revealed that model-simulated $\mathrm{O}_{3}$ mixing ratios within the boundary layer were significantly underestimated during spring-summer compared with ARCTAS measurements. More recently, Monks et al. (2015) further demonstrated that model-simulated $\mathrm{O}_{3}$ mixing ratios in the Arctic at the surface and in the upper troposphere were generally lower than the observations. In addition, a recent study by Christian et al. (2017) compared $\mathrm{O}_{3}$ observations from the ARCTAS campaign to GEOS-Chem model simulations and found consistent low biases with the model-simulated $\mathrm{O}_{3}$ at all altitudes except the surface.

Field measurements at Summit show that the snowpack emits gas-phase $\mathrm{NO}_{x}$, PAN, nitrous acid (HONO), and hydrogen peroxide $\left(\mathrm{H}_{2} \mathrm{O}_{2}\right)$ during spring-summer when the polar sun rises (Ford et al., 2002; Honrath et al., 2002). Although several 1-D models (Thomas et al., 2011, 2012; Frey et al., 2013; Murray et al., 2015) have validated the importance of snowpack emissions for surface $\mathrm{NO}_{x}$ and $\mathrm{O}_{3}$ formation, current global chemical transport models (CTMs) usually do not include these emission sources (Zatko et al., 2016).

In this study, we examine the abundance and seasonal variations of $\mathrm{O}_{3}$ and its precursors at Summit with a global chem- ical transport model, GEOS-Chem CTM, in conjunction with 2 years of in situ measurement data for 2008-2010. We first evaluate the model performance in simulating surface $\mathrm{O}_{3}$ and its precursors and then implement a series of model updates to resolve the identified model biases. This paper is organized as follows: Sect. 2 describes model methods and observations, followed by detailed comparisons of model simulations against observations for $\mathrm{O}_{3}$ and $\mathrm{O}_{3}$ precursors in Sect. 3; conclusions are summarized in Sect. 4.

\section{Observational data and model simulations}

In situ measurements of $\mathrm{NO}_{x}$, PAN, and non-methane hydrocarbons (NMHCs) were performed at Summit from July 2008 to June 2010 (Helmig et al., 2014b; Kramer et al., 2015). An automated chemiluminescence instrument was used to measure $\mathrm{NO}_{x}$ (Ridley and Grahek, 1990), and a commercial PAN gas chromatography analyzer (PAN-GC; Metcon, Inc., Boulder, CO, USA) was employed for the measurement of PAN. Measurements of NMHC relied on an automated gas chromatography-flame ionization detection (GC-FID) system. Readers are referred to Kramer et al. (2015) and Helmig et al. (2014b) for the details of the measurement techniques and equipment setup. In situ surface measurements of $\mathrm{O}_{3}$ at Summit using an ultraviolet light absorption technique (Petropavlovskikh and Oltmans, 2012) and CO data from weekly flask sampling with analysis by using a $\mathrm{GC}-\mathrm{HgO}$ reduction detection instrument (Novellie et al., 2003) and an analyzer based on CO fluorescence in the ultraviolet vacuum (Gerbig et al., 1999) were conducted by the National Oceanic and Atmospheric Administration (NOAA) and downloaded from the NOAA Earth System Research Laboratory (ESRL) Global Monitoring Division (GMD) website (http://www.esrl.noaa.gov/ $\mathrm{gmd} / \mathrm{dv} / \mathrm{data} /$ ) for the period between July 2008 and June 2010. Vertical ozonesonde data profiles were also downloaded from NOAA ESRL GMD (McClure-Begley et al., 2014).

Simulations of $\mathrm{O}_{3}$ and related species $\left(\mathrm{NO}_{x}\right.$, PAN, NMHCs) were conducted using the GEOS-Chem model (Bey et al., 2001) with a coupled $\mathrm{O}_{3}-\mathrm{NO}_{x}-\mathrm{VOC}$-aerosol chemistry mechanism (i.e., these species interact with each other in the model). The GEOS-Chem CTM is driven by assimilated meteorological data from the Goddard Earth Observing System version 5.2.0 (GEOS-5.2.0) of the NASA Global Modeling Assimilation Office. The GEOS-Chem model has been extensively evaluated and applied in a wide range of applications (Martin et al., 2002; Park et al., 2004; Wu et al., 2007; Hudman et al., 2009; Johnson et al., 2010; Huang et al., 2013; Kumar et al., 2013; Zhang et al., 2014; Hickman et al., 2017), including studies in the Arctic (e.g., Alvarado et al., 2010; Monks et al., 2015; Christian et al., 2017). GEOS-Chem v10-1, with a grid resolution of $4^{\circ}$ latitude by $5^{\circ}$ longitude and 47 vertical layers, was used for the 

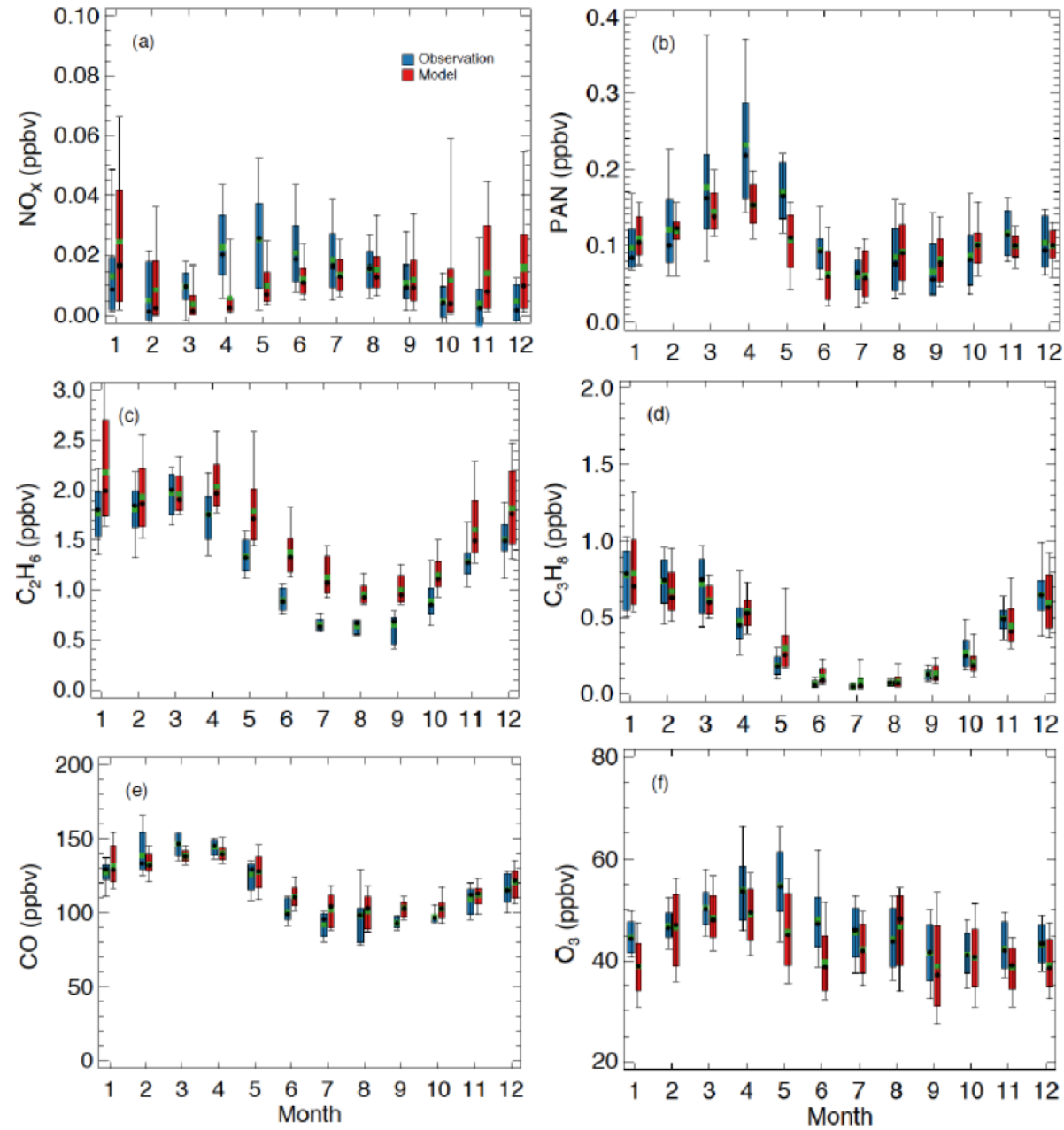

Figure 1. Box plot comparison for seasonal variations in (a) $\mathrm{NO}_{x}$, (b) PAN, (c) $\mathrm{C}_{2} \mathrm{H}_{6}$, (d) $\mathrm{C}_{3} \mathrm{H}_{8}$, (e) $\mathrm{CO}$, and (f) $\mathrm{O}_{3}$ between GEOS-Chem model simulations (red) and measurements (blue) at Summit for the period July 2008-June 2010. Data shown are monthly averages during this period. The thick (thin) bars represent the $67 \%$ (95\%) confidence intervals. Black and green dots represent median and mean values, respectively. The statistics are based on daily averages.

Table 1. Surface $\mathrm{NO}_{2}$ measurements over Europe during 1 December 2009-31 January 2010.

\begin{tabular}{llrrlll}
\hline Site ID & Site name & Lat. $\left({ }^{\circ} \mathrm{N}\right)$ & Lon. $\left({ }^{\circ} \mathrm{E}\right)$ & Altitude a.s.l $(\mathrm{m})$ & Technique & Resolution \\
\hline BE0001R & Offagne & 49.88 & 5.20 & 430 & chemiluminescence & hourly \\
BE0032R & Eupen & 50.63 & 6.00 & 295 & chemiluminescence & hourly \\
DE0001R & Westerland & 54.93 & 8.31 & 12 & NaJ_solution & daily \\
DK0008R & Anholt & 56.72 & 11.52 & 40 & UV_fluorescence & hourly \\
FI0096G & Pallas & 67.97 & 24.12 & 340 & chemiluminescence & hourly \\
GB0014R & High Muffles & 54.33 & -0.80 & 267 & chemiluminescence & daily \\
NL0009R & Kollumerwaard & 53.33 & 6.28 & 1 & chemiluminescence & hourly \\
NO0001R & Birkenes & 58.38 & 8.25 & 190 & glass sinter & daily \\
NO0039R & Kårvatn & 62.78 & 8.88 & 210 & glass sinter & daily \\
NO0056R & Hurdal & 60.37 & 11.08 & 300 & glass sinter & daily \\
SE0005R & Bredkälen & 63.85 & 15.3 & 404 & abs_tube & daily \\
\hline
\end{tabular}


model control simulation. Following McLinden et al. (2000), the Linoz stratospheric $\mathrm{O}_{3}$ chemistry scheme was used. The simulation was run from June 2007 to June 2010, and the results from the last 2 years were used in the final analysis. Time series data were archived with $3 \mathrm{~h}$ temporal resolution at the Summit grid box for each model vertical level, including the model bottom layer. For comparison with surface observations at Summit, Greenland, we sampled the data for the model bottom layer. We acknowledge that the topography in GEOS-Chem model is not well resolved at such a coarse model resolution ( $4^{\circ}$ latitude by $5^{\circ}$ longitude), and we used the model bottom layer at the Summit grid cell for $\mathrm{O}_{3}$ and its precursor concentrations to compare with surface observations, which worked better than sampling $\mathrm{O}_{3}$ and its precursor concentrations at the model vertical layer at about $3212 \mathrm{~m}$ a.s.l. (above the sea level; Summit's elevation).

Global anthropogenic emissions of $\mathrm{NO}_{x}, \mathrm{SO}_{2}, \mathrm{NH}_{3}$, and $\mathrm{CO}$ in the model were based on the Emission Database for Global Atmospheric Research (EDGAR) v4.2 inventory, which was overwritten by regional emission inventories where applicable, such as the BRAVO inventory for Mexico (Kuhns et al., 2005), the CAC over Canada, the EMEP emissions over Europe, the Model Inter-comparison Study for Asia Phase III (MIX) emissions over Asia (Li et al., 2017), and the US EPA NEI 2011 (NEI11) emission inventory (Simon et al., 2010). The soil $\mathrm{NO}_{x}$ emission scheme followed Hudman et al. (2012). Lightning $\mathrm{NO}_{x}$ emissions were calculated per flash rate based on GEOS-5 computed cloud-top heights (Price and Rind, 1992), which were determined by deep convection and constrained by satellite observations for monthly average flash rates from the Lightning Imaging Sensor and Optical Transient Detector (OTD/LIS; Sauvage et al., 2007; Murray et al., 2012). Biomass burning emissions were from the Global Fire Emissions Database version 4 (GFED4) inventory with monthly resolution (Giglio et al., 2013). The RETRO (Reanalysis of the TROpospheric chemical composition) global anthropogenic NMHC emission inventory (van het Bolscher et al., 2008) was used except for ethane $\left(\mathrm{C}_{2} \mathrm{H}_{6}\right)$ and propane $\left(\mathrm{C}_{3} \mathrm{H}_{8}\right)$, which followed Xiao et al. (2008, hereafter referred to as X08) for the year 2001. In GEOS-Chem, RETRO served as the default global anthropogenic emission inventory for $\mathrm{C}_{2} \mathrm{H}_{6}$, the annual budget of which has been as shown too low compared with observations. The global biofuel emission inventory followed Yevich and Logan (2003), which included emissions for $\mathrm{C}_{2} \mathrm{H}_{6}$ and $\mathrm{C}_{3} \mathrm{H}_{8}$. For biogenic VOC emissions, the Model of Emissions of Gases and Aerosols from Nature (MEGAN) scheme (Guenther et al., 2006) was used. The dry deposition of species in GEOS-Chem used a standard resistance-in-series scheme (Wesely, 1989), as implemented in Wang et al. (1998). Wet scavenging followed Liu et al. (2001), including scavenging in convective updraft, rainout (in-cloud), and washout (below-cloud) from convective anvils and large-scale precipitation.

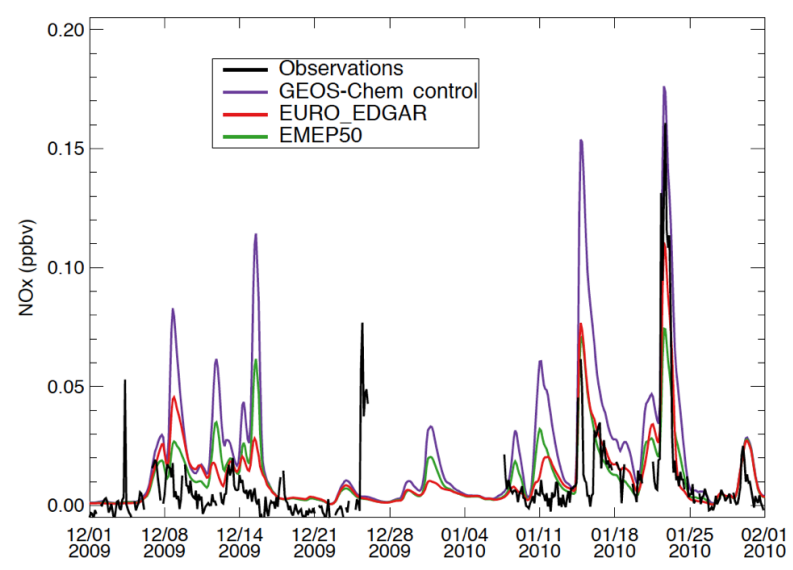

Figure 2. Time series of surface $\mathrm{NO}_{x}$ mixing ratios over Summit from observations, GEOS-Chem model control simulations, EURO_EDGAR, and EMEP50 during 1 December 2009-31 January 2010. EURO_EDGAR represents simulations with anthropogenic $\mathrm{NO}_{x}$ emissions over Europe following EDGAR v4.2, while EMEP50 denotes simulations with anthropogenic $\mathrm{NO}_{x}$ emissions from the EMEP emission inventory over Europe reduced by $50 \%$; other model configurations are identical to the control simulations.

We first ran the standard GEOS-Chem model with a priori emissions and compared the simulation results against observations for various species (including $\mathrm{NO}_{x}, \mathrm{PAN}, \mathrm{C}_{2} \mathrm{H}_{6}$, $\mathrm{C}_{3} \mathrm{H}_{8}, \mathrm{CO}$, and $\mathrm{O}_{3}$, as shown in Fig. 1). Then we focused on the model-observation discrepancies and where applicable made revisions to the model simulations and further evaluated the improvement in model performance, as discussed in detail below.

\section{Results and discussion}

\section{$3.1 \mathrm{NO}_{x}$}

We first combined the 2 years of data for July 2008June 2010 and analyzed their seasonal variations. As shown in Fig. 1a, the GEOS-Chem model-simulated $\mathrm{NO}_{x}$ agrees well with the observations for July-October. However, compared to observations, the model results significantly overestimate $\mathrm{NO}_{x}$ mixing ratios for November-January by about $150 \%$ while underestimating the data in spring and early summer by approximately $60 \%$. Another challenge for the model simulation is that it does not capture the decrease in $\mathrm{NO}_{x}$ for May-November. We find that during the 2009-2010 winter season, model simulations show several high $\mathrm{NO}_{x}$ spikes with peak $\mathrm{NO}_{x}$ mixing ratios reaching $\sim 0.15$ ppbv or higher, which is $\sim 15$ times greater than typical background levels (Fig. 2). These large peaks in $\mathrm{NO}_{x}$ were not observed in the data. Similar peaks were also seen in the model simulations during the 2008-2009 winter season; however, there are no measurements available for this period to compare with. 


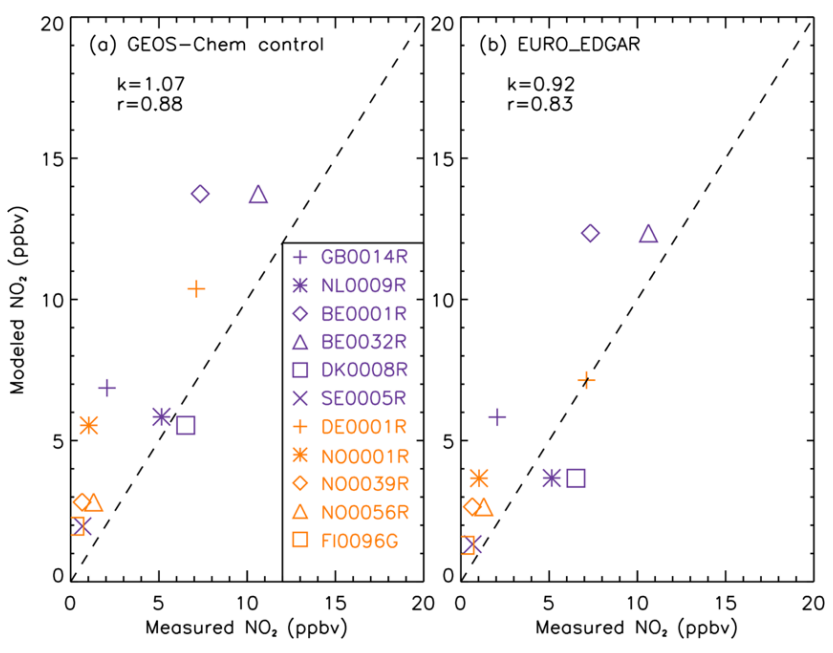

Figure 3. Scatter plots of model simulations from (a) GEOS-Chem control simulations and (b) EURO_EDGAR during 1 December 2009-31 January 2010 and measured monthly mean $\mathrm{NO}_{2}$ mixing ratios at 11 observational sites over Europe; also shown are the corresponding model-to-observation slopes $(k)$ and correlation coefficients $(r)$ for each panel. The dashed line is the $1: 1$ ratio. Explanations of site abbreviations are listed in Table 1. EURO_EDGAR represents simulations with anthropogenic $\mathrm{NO}_{x}$ emissions over Europe following EDGAR v4.2, with other model configurations identical to the control simulations.

Further analyses showed that the model-simulated high $\mathrm{NO}_{x}$ spikes during wintertime were all associated with transport events from Europe. We carried out a sensitivity study to examine the impacts of European emissions on Arctic $\mathrm{NO}_{x}$ by manually reducing anthropogenic $\mathrm{NO}_{x}$ emissions from the EMEP emission inventory over Europe by $50 \%$ (EMEP50). The results showed that surface peak $\mathrm{NO}_{x}$ mixing ratios over Summit during the spike events (e.g., dates around 9 and 15 December 2009, 15 and 22 January 2010) from EMEP50 declined almost proportionally by $\sim 50 \%$ during 1 December 2009-31 January 2010 (Fig. 2), which confirmed that the modeled $\mathrm{NO}_{x}$ spikes at Summit during wintertime were associated with transport from Europe. However, the model-simulated $\mathrm{NO}_{x}$ was still significantly higher than observations. Comparisons for surface $\mathrm{NO}_{2}$ mixing ratios between model simulations and 11 in situ observational sites over Europe during this period were conducted with data downloaded from http://ebas.nilu.no. For detailed site information and the $\mathrm{NO}_{2}$ measurement technique and resolution, refer to Table 1 . Measurement data over these 2 months for each site were averaged to compare with the corresponding grid cell in the model. As shown in Fig. 3a, GEOS-Chem overestimated surface $\mathrm{NO}_{2}$ mixing ratios at these sites by over $66 \%$ compared with observations (slope $=1.07$; correlation coefficient $=0.88$ ).

In addition to using EMEP, we carried out another sensitivity study to force anthropogenic $\mathrm{NO}_{x}$ emissions over Europe following EDGAR v4.2 (EURO_EDGAR), with other model configurations identical to control simulations. As shown in Fig. 2, the $\mathrm{NO}_{x}$ mixing ratios over Summit during December 2009-January 2010 agreed much better with observations, especially for January 2010 when the model captured the magnitudes of observational peaks. This is because $\mathrm{NO}_{x}$ emissions from EDGAR over Europe (1.97 Tg NO) were $12 \%$ lower than those from EMEP (2.24 Tg NO) for the months of December 2009 and January 2010. Furthermore, the discrepancy for the differences in surface $\mathrm{NO}_{2}$ mixing ratios over Europe between EURO_EDGAR and observations was further reduced (by $50 \%$ ) relative to the control runs, with a model-to-observation slope of 0.92 and a correlation coefficient of 0.83 (Fig. 3b). Similarly, we also tested the sensitivity of surface $\mathrm{NO}_{x}$ mixing ratios over Summit in response to the changes in the anthropogenic $\mathrm{NO}_{x}$ emissions from NEI11 over the US and MIX over Asia (including Siberia) during these 2 months and found that surface $\mathrm{NO}_{x}$ mixing ratios over Summit during these 2 months were quite close to the control simulations (not shown), reflecting insensitivity to emission perturbations from the US and Asia. Therefore, we conclude that uncertainties in fossil fuel $\mathrm{NO}_{x}$ emissions of EMEP associated with transport events from Europe in the model are the most likely cause for the wintertime $\mathrm{NO}_{x}$ spikes over Summit.

For April-July, model-simulated monthly mean $\mathrm{NO}_{x}$ mixing ratios over Summit were a factor of 2 lower than the observations (Fig. 4a). Experiments at Summit by Honrath et al. (1999, 2000a, b, 2002) showed upward fluxes of $\mathrm{NO}_{x}$ $\left(2.52 \times 10^{8}\right.$ molecules $\left.\mathrm{cm}^{-2} \mathrm{~s}^{-1}\right)$ from the photolysis of nitrate in snowpack during the summertime, leading to an enhancement of $\mathrm{NO}_{x}$ levels in the surface layer by approximately 20 pptv, which was comparable to surface $\mathrm{NO}_{x}$ mixing ratios in the Arctic from other sources. Similar results were found over the East Antarctic Plateau snow and ice sheet (Frey et al., 2013; Legrand et al., 2014). The standard GEOS-Chem model did not include the photolysis of nitrate from snowpack, implying a missing source for $\mathrm{NO}_{x}$ in the Arctic-Antarctic boundary layer.

In order to test the sensitivity of model-simulated surface $\mathrm{NO}_{x}$ mixing ratios to the snowpack emissions, we implemented in the model a constant $\mathrm{NO}_{x}$ flux of $\sim 2.52 \times 10^{8}$ molecules $\mathrm{cm}^{-2} \mathrm{~s}^{-1}$ during April-July over Greenland $\left(60-85^{\circ} \mathrm{N}, 20-60^{\circ} \mathrm{W}\right)$, following the measurements conducted at Summit during summertime by Honrath et al. (2002). As a result, we found that on average the modelsimulated surface $\mathrm{NO}_{x}$ mixing ratios for April to July over Summit more than doubled compared to the control simulation, which improved the agreement between the model and observations for April-June (Fig. 4a). However, the assumed $\mathrm{NO}_{x}$ flux from snowpack in the model led to an overestimation of $\mathrm{NO}_{x}$ mixing ratios in July, and the model was still not able to reproduce the decreasing trend of $\mathrm{NO}_{x}$ for May-October. This decreasing trend of $\mathrm{NO}_{x}$ may be driven by the decreasing $\mathrm{NO}_{x}$ production rate in snowpack resulting from a gradual depletion of the snowpack $\mathrm{NO}_{x}$ reservoir 

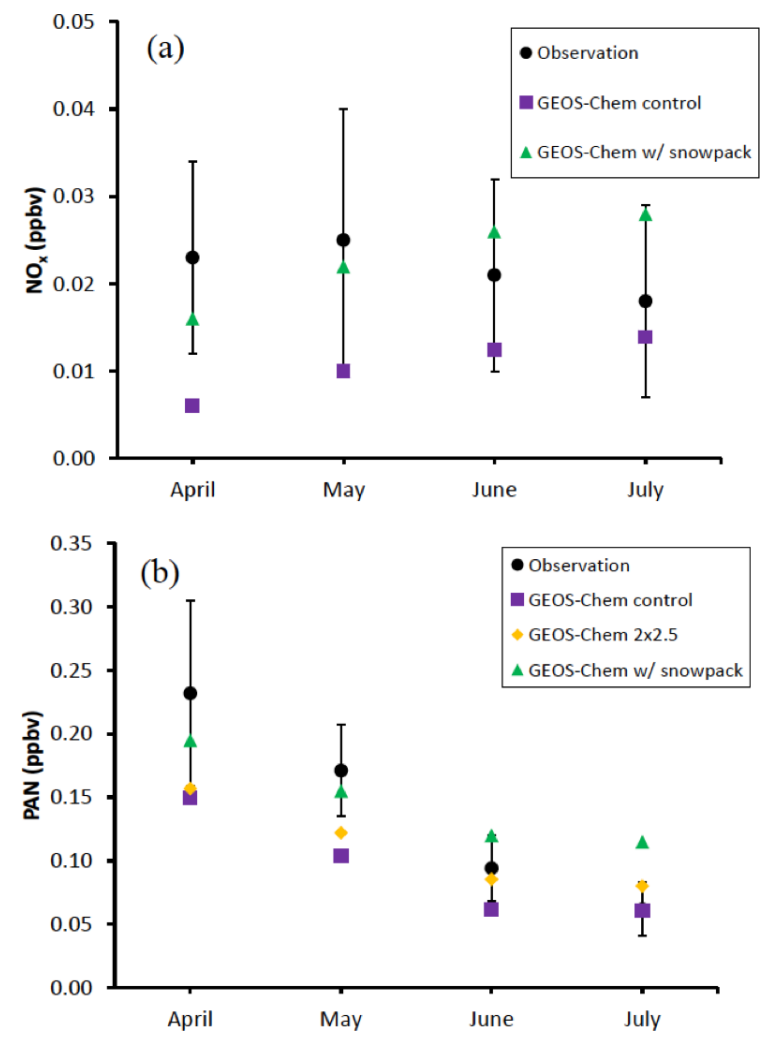

Figure 4. Monthly mean surface (a) $\mathrm{NO}_{x}$ and (b) PAN mixing ratios from observations (black circles), simulations with (green triangles) and without (purple squares) snowpack emissions, and GEOSChem simulations with a horizontal grid resolution of $2^{\circ} \times 2.5^{\circ}$ (orange diamonds) for April-July during July 2008-June 2010. Vertical bars denote standard deviations over the course of observations for each month.

(Van Dam et al., 2015), which is not reflected in the model since we implemented a simple constant $\mathrm{NO}_{x}$ emission flux. Dibb et al. (2007) reported that nitrate concentrations in the Summit snowpack peaked in June and declined toward fall by $\sim 1 / 3$. Van Dam et al. (2015) further showed a decreasing trend for $\mathrm{NO}_{x}$ mixing ratios within the snowpack at Summit from June to October. This may partially explain why we would see the declining trend of surface $\mathrm{NO}_{x}$ mixing ratios over Summit from June toward fall. The $\mathrm{NO}_{x}$ emissions from snowpack are affected by a number of factors, including nitrate concentrations and the solar radiation available, and the responses can be very nonlinear. Further investigations are needed to account for the seasonal variations in snowpack $\mathrm{NO}_{x}$ emissions from nitrate photolysis in the model, i.e., constrained by seasonal snowpack $\mathrm{NO}_{x}$ emission flux measurements in the future.

\subsection{PAN}

We then examined the model performance for PAN, which serves as a reservoir for $\mathrm{NO}_{x}$. Figure $1 \mathrm{~b}$ shows the compar- ison of model-simulated monthly mean PAN mixing ratios with the measurement data. The model captured the seasonal variation of PAN well, although it significantly (by $~ 30 \%$ ) underestimated the PAN mixing ratios for April-June. By running the model simulation with higher horizontal resolution at $2^{\circ}$ latitude by $2.5^{\circ}$ longitude (hereafter referred to as GEOS-Chem $2 \times 2.5$ ), we found that the monthly mean PAN mixing ratios over Summit during April-July increased by up to 23.3 pptv compared to the $4 \times 5$ simulation (Fig. $4 b$ ). This can be explained by two factors. First, the coarse model resolution (e.g., $4 \times 5$ horizontal resolution) could artificially smear the intense emission sources throughout the entire grid cell (e.g., over urban regions), leading to underestimates of downwind concentrations for species like $\mathrm{O}_{3}$ and $\mathrm{O}_{3}$ precursors (Jang et al., 1995; Yu et al., 2016). Second, ventilation in the lower atmosphere could be better resolved by a finer model resolution, leading to more efficient vertical advection (Wang et al., 2004; Chen et al., 2009; Yu et al., 2016). However, on average, the monthly mean model-simulated PAN mixing ratios were still underestimated by $20 \%$ during this period compared with observations. This is consistent with the study by Arnold et al. (2015), which reported that modelsimulated PAN mixing ratios in GEOS-Chem were lower than ARCTAS observations in the Arctic. Meanwhile, this study also revealed that GEOS-Chem produced less PAN relative to $\mathrm{CO}$ in Arctic air parcels that were influenced by fires compared with other models.

Snowpack can emit not only $\mathrm{NO}_{x}$, but also PAN as indicated based on field studies at Summit during summertime by Ford et al. (2002). GEOS-Chem did not contain snowpack PAN emissions and chemistry. For a sensitivity study similar to snowpack $\mathrm{NO}_{x}$ emissions as discussed in Sect. 3.1, we considered a $24 \mathrm{~h}$ constant flux of $2.52 \times 10^{8}$ molecules $\mathrm{cm}^{-2} \mathrm{~s}^{-1}$ of PAN over Greenland from April to July, following Ford et al. (2002). As a result, modelsimulated PAN mixing ratios agreed much better with observations (Fig. 4b). Note that there are also other possible factors that lead to model bias. For instance, a study by Fischer et al. (2014) showed improved agreement between modeled and measured PAN in the high latitudes when assigning a portion of the fire emissions in the model above the boundary layer and also directly partitioning $40 \%$ of $\mathrm{NO}_{x}$ emissions from fires into PAN. We carried out a sensitivity test with similar treatments, but no significant improvements in the model-simulated surface PAN were observed at the Summit site. Therefore, we did not include the PAN updates from Fischer et al. (2014) in other model simulations in this study.

\subsection{NMHC}

Comparisons of observed surface $\mathrm{C}_{2} \mathrm{H}_{6}$ and $\mathrm{C}_{3} \mathrm{H}_{8}$ mixing ratios with GEOS-Chem simulations at Summit are shown in Fig. 1c and d. The model simulations agreed well with surface measurements of $\mathrm{C}_{3} \mathrm{H}_{8}$ but systematically overestimated $\mathrm{C}_{2} \mathrm{H}_{6}$ (by approximately $25 \%$ annually), with the largest bias 
( $0.48 \mathrm{ppbv)}$ occurring during summer. This is consistent with the study from Tzompa-Sosa et al. (2017), which used the same model as our study and pointed out that using X08 as a global anthropogenic $\mathrm{C}_{2} \mathrm{H}_{6}$ emission inventory systematically overestimated surface $\mathrm{C}_{2} \mathrm{H}_{6}$ mixing ratios over the Northern Hemisphere compared with ground-based observations. Anthropogenic $\mathrm{C}_{2} \mathrm{H}_{6}$ emissions over the US from NEI11 were shown to geographically match the distribution of active oil and natural wells (Tzompa-Sosa et al., 2017), and the most recent MIX has been updated to synergize anthropogenic $\mathrm{C}_{2} \mathrm{H}_{6}$ emissions from various countries in Asia (Li et al., 2017). Therefore, instead of using global anthropogenic fossil fuel emissions of $\mathrm{C}_{2} \mathrm{H}_{6}$ following X08, we first conducted sensitivity simulations by overwriting global emission inventories by NEI11 over the US and MIX over Asia (hereafter referred to as NEI11_MIX). Both NEI11 and MIX contain emissions for the years from 2008 to 2010, which could realistically represent the annual and seasonal variations in $\mathrm{C}_{2} \mathrm{H}_{6}$ emissions over the US and Asia and thus be spatially and temporally more representative of anthropogenic $\mathrm{C}_{2} \mathrm{H}_{6}$ emissions from the midlatitudes transported to the Arctic regions. In general, model control simulations overestimated annual mean surface $\mathrm{C}_{2} \mathrm{H}_{6}$ mixing ratios primarily in the Northern Hemisphere, with large differences occurring over Asia and the US by up to 5 ppbv compared with NEI11_MIX during the period July 2008-June 2010 (Fig. S1 in the Supplement). All the above changes were driven by the substantial reductions of anthropogenic $\mathrm{C}_{2} \mathrm{H}_{6}$ emissions between emission inventories, from 3.5 (X08) to 2.5 $\mathrm{Tg} \mathrm{year}^{-1}$ (MIX) over Asia and from 1.9 $\mathrm{Tg} \mathrm{year}^{-1}$ (X08) to $1.4 \mathrm{Tg}_{\text {year }}{ }^{-1}$ (NEI11) over the US, reflecting the decreasing trend of anthropogenic $\mathrm{C}_{2} \mathrm{H}_{6}$ emissions during 20012009 (Helmig et al., 2014a) because the X08 emission inventory is based on the year 2001. Substantial changes in surface $\mathrm{C}_{2} \mathrm{H}_{6}$ mixing ratios over the US between control simulations and NEI11_MIX reflected tempo-spatial changes in $\mathrm{C}_{2} \mathrm{H}_{6}$ emissions from oil and gas production during the period 2001-2009. A similar pattern was also found by TzompaSosa et al. (2017). In contrast to the control simulations, NEI11_MIX model simulations showed that monthly mean $\mathrm{C}_{2} \mathrm{H}_{6}$ mixing ratios over Summit were systematically underestimated by $24 \%$ compared with observations (Fig. 5). Tzompa-Sosa et al. (2017) reported that NEI11 $\mathrm{C}_{2} \mathrm{H}_{6}$ emissions were likely underestimated by $40 \%$ compared with in situ and aircraft observations over the US. We therefore ran a sensitivity simulation by increasing the NEI11 $\mathrm{C}_{2} \mathrm{H}_{6}$ emissions by $40 \%$ and keeping other model configurations identical to NEI11_MIX (hereafter referred to as NEI11_40_MIX). We found that this update led to an increase in the model-simulated annual mean surface $\mathrm{C}_{2} \mathrm{H}_{6}$ mixing ratios over Summit by only $6 \%$ during the period July 2008-June 2010 (figure not shown), which still does not explain the high model bias.

Similar to NEI11_MIX, we further conducted sensitivity studies by only replacing the regional emission inven-

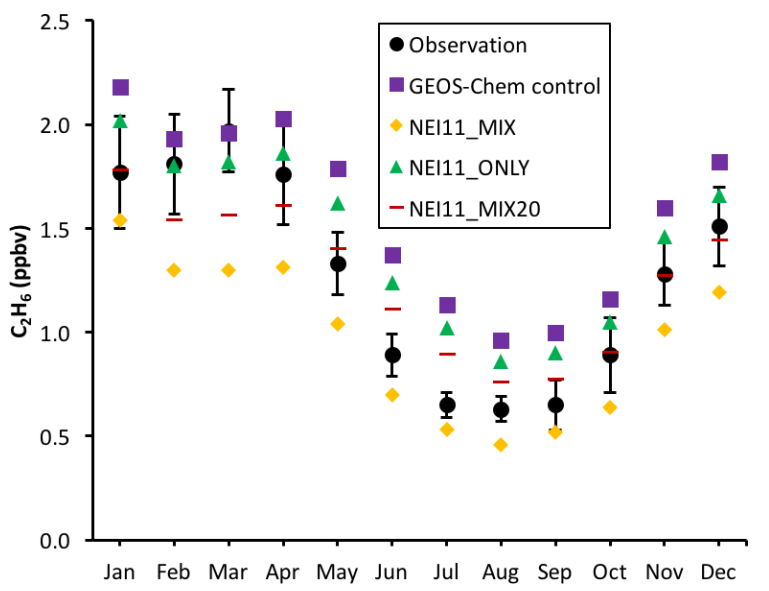

Figure 5. Monthly mean surface $\mathrm{C}_{2} \mathrm{H}_{6}$ mixing ratios at Summit from observations (black circles), GEOS-Chem model control simulations (purple squares), NEI11_MIX (orange diamond), and NEI11_ONLY (green triangles) simulations during 2008-2010; vertical bars denote the standard deviation over the course of observations for each month. NEI11_MIX represents model perturbations with global $\mathrm{C}_{2} \mathrm{H}_{6}$ emission inventories overwritten by NEI1 1 over the US and by MIX over Asia, with other model configurations identical to the control simulations. NEI11_ONLY denotes the simulation that is the same as the control simulation, except that the $\mathrm{C}_{2} \mathrm{H}_{6}$ emission inventory over the US is overwritten by NEI11. NEI11_MIX20 is the simulation that is identical to NEI11_MIX except for the $20 \%$ increased MIX $\mathrm{C}_{2} \mathrm{H}_{6}$ emission inventory over Asia.

tory for $\mathrm{C}_{2} \mathrm{H}_{6}$ over the US, with other regions still following X08 (hereafter referred to as NEI11_ONLY). Consequently, model-simulated surface $\mathrm{C}_{2} \mathrm{H}_{6}$ mixing ratios over Summit agreed better with observations during winter-spring (Fig. 5), decreasing the bias from $+15 \%$ (control simulations) to $+6 \%$. However, model-simulated $\mathrm{C}_{2} \mathrm{H}_{6}$ mixing ratios during summer-fall were higher than the observations by over $30 \%$.

We then scaled up the MIX emissions for $\mathrm{C}_{2} \mathrm{H}_{6}$ by $20 \%$ over Asia, with other model configurations identical to NEI11_MIX (hereafter referred to as NEI11_MIX20). By doing this, we increased fossil fuel $\mathrm{C}_{2} \mathrm{H}_{6}$ emissions from 2.5 to $3 \mathrm{Tg}_{\text {year }}{ }^{-1}$. We found that the simulated annual mean surface $\mathrm{C}_{2} \mathrm{H}_{6}$ mixing ratios at Summit from NEI11_MIX20 agreed quite well with observations (within $1 \%$ ). Similarly, better agreement between the model and observations were found for monthly average values for October-January. However, the new simulation was not able to reproduce the seasonal cycle of $\mathrm{C}_{2} \mathrm{H}_{6}$; the model significantly underestimated $\mathrm{C}_{2} \mathrm{H}_{6}$ in February-April but overestimated it in JuneSeptember (Fig. 5). This implies that further assessments of anthropogenic $\mathrm{C}_{2} \mathrm{H}_{6}$ emissions from MIX over Asia are needed and a more accurate global anthropogenic $\mathrm{C}_{2} \mathrm{H}_{6}$ emission inventory should be developed and validated to replace X08 in the future. It should be noted that our modeling 
period reflects a time when there was a reversal of the atmospheric $\mathrm{C}_{2} \mathrm{H}_{6}$ trend, most likely reflecting emission changes during that time. Atmospheric $\mathrm{C}_{2} \mathrm{H}_{6}$ had a decreasing trend from 1980 to 2009 (Simpson et al., 2012; Helmig et al., 2014a) but then began to increase around 2009 (Franco et al., 2015, 2016; Hausmann et al., 2016; Helmig et al., 2016) in the Northern Hemisphere at a rate of increase that is approximately 4-6 times higher than its earlier rate of decline. It has been argued that the most likely cause for this trend and emission reversal is increasing emissions from oil and gas production, mostly from North America (Franco et al., 2015, 2016; Hausmann et al., 2016; Helmig et al., 2016). None of the considered inventories considered these emission changes and their timing. Also note that this standard version of GEOS-Chem does not account for the sink of $\mathrm{C}_{2} \mathrm{H}_{6}$ from the reaction with chlorine, which could reduce the global annual mean surface $\mathrm{C}_{2} \mathrm{H}_{6}$ mixing ratios by 0 $30 \%$ and the global burden of $\mathrm{C}_{2} \mathrm{H}_{6}$ by about $20 \%$ (Sherwen et al., 2016). This omission likely introduces additional uncertainty into our measurement-model comparison together with uncertainty in the seasonality of $\mathrm{C}_{2} \mathrm{H}_{6}$ chemistry.

\subsection{CO}

Figure 1e shows the comparison of model-simulated CO mixing ratios with observations over Summit. Overall, the model generally captures the abundance and seasonal variation of $\mathrm{CO}$. Compared with observations, the annual mean $\mathrm{CO}$ mixing ratio was slightly overestimated by about $3 \mathrm{ppbv}$ in the model.

\section{$\begin{array}{ll}3.5 & \mathrm{O}_{3}\end{array}$}

Surface $\mathrm{O}_{3}$ mixing ratios from model simulations and surface observations are compared in Fig. 1f. The GEOS-Chem model captured the seasonal variation of $\mathrm{O}_{3}$ including the spring peak. However, the model shows a systematic low bias for most of the year, in particular for April-July when the surface $\mathrm{O}_{3}$ mixing ratios were underestimated by $\sim 13 \%$ $(\sim 6.5 \mathrm{ppbv})$. Here we focus our analysis on the possible causes that led to the model low bias during April-July.

As discussed earlier, snowpack emissions due to the photolysis of nitrate in the snow during late spring and summer could contribute to $\mathrm{NO}_{x}$ and HONO levels in the ambient air, which could enhance $\mathrm{O}_{3}$ production (Crawford et al., 2001; Zhou et al., 2001; Dibb et al., 2002; Honrath et al., 2002; Yang et al., 2002; Grannas et al., 2007; Helmig et al., 2008; Legrand et al., 2014). We ran a sensitivity study to test the response of surface $\mathrm{O}_{3}$ mixing ratios to the perturbations of $\mathrm{NO}_{x}$ and HONO from snowpack emissions. In addition to snowpack $\mathrm{NO}_{x}$ emissions that are described in Sect. 3.1, we implemented in the model a constant flux of HONO $\left(4.64 \times 10^{7}\right.$ molecules $\left.\mathrm{cm}^{-2} \mathrm{~s}^{-1}\right)$ from April to July (Honrath et al., 2002). As a result, monthly mean modelsimulated surface $\mathrm{O}_{3}$ mixing ratios increased by up to $3 \mathrm{ppbv}$

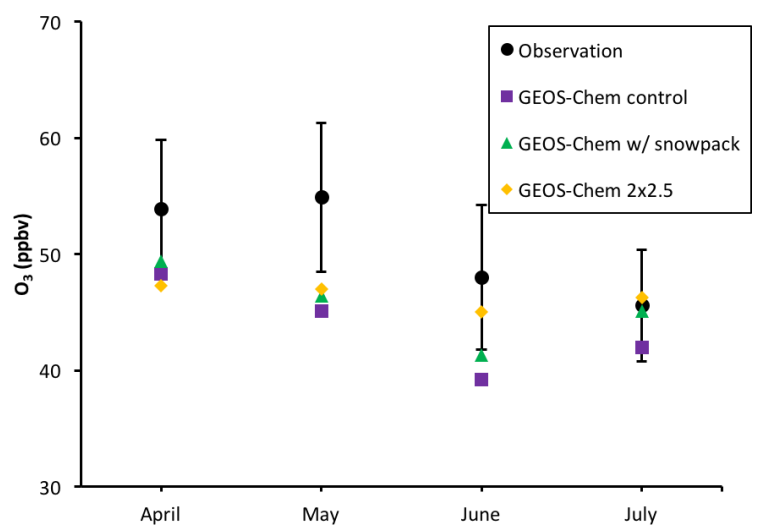

Figure 6. Monthly mean surface $\mathrm{O}_{3}$ mixing ratios from observations (black circles), GEOS-Chem control runs (purple squares), simulations with snowpack chemistry (green triangles), and simulations with a horizonal grid resolution of $2^{\circ} \times 2.5^{\circ}$ (orange diamonds) for April-July. Vertical bars denote the variability over the course of observations for each month.

during this period (Fig. 6). The largest effect occurred in July due to relatively strong solar radiation. $\mathrm{O}_{3}$ formation due to the snowpack emissions in our study was slightly higher than that in Zatko et al. (2016) because HONO from snowpack emissions was not considered in their study. However, for the months of April and May, surface $\mathrm{O}_{3}$ mixing ratios only increased by $\sim 1 \mathrm{ppbv}$ compared with the control runs. That is, even after accounting for the snowpack emissions, the model-simulated $\mathrm{O}_{3}$ mixing ratios were still significantly lower than the observations.

A comparison of the model simulations at different resolutions $(4 \times 5$ vs. $2 \times 2.5)$ showed that the finer-resolution simulations substantially increased monthly mean $\mathrm{O}_{3}$ mixing ratios over Summit by up to $6 \mathrm{ppbv}$ for the months of June and July (Fig. 6). As discussed in Sect. 3.2, a fine model resolution can better resolve the emission strengths, which could significantly affect downwind chemical reactions like $\mathrm{O}_{3}$ production efficiency (Liang and Jacobson, 2000). Moreover, terrain elevations from fine model resolution are better represented (thus more representative of Summit's elevation), and more efficient vertical ventilation of $\mathrm{O}_{3}$ and $\mathrm{O}_{3}$ precursors can be achieved (Wang et al., 2004). Together with the impact of snowpack chemistry, this brought modelsimulated surface $\mathrm{O}_{3}$ mixing ratios over Summit into better agreement with observations for June-July. However, there was still a low bias in the model for the months of April and May.

Another possible cause for the low $\mathrm{O}_{3}$ biases in model simulations is the calculated stratosphere-to-troposphere exchange (STE) $\mathrm{O}_{3}$ flux in the model. Liang et al. (2011) have pointed out that STE could be a significant direct source of $\mathrm{O}_{3}$ in the Arctic during spring-summer. We retrieved vertical profiles of $\mathrm{O}_{3}$ mixing ratios and specific humidity from ozonesondes ( $0-5 \mathrm{~km}$ of elevation above the Summit surface) 


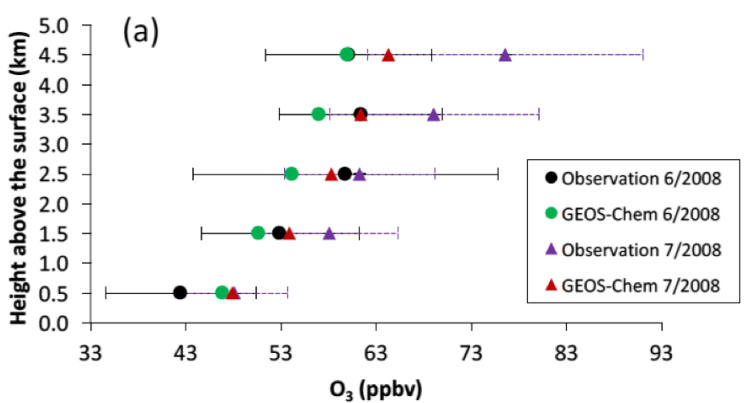

(b)

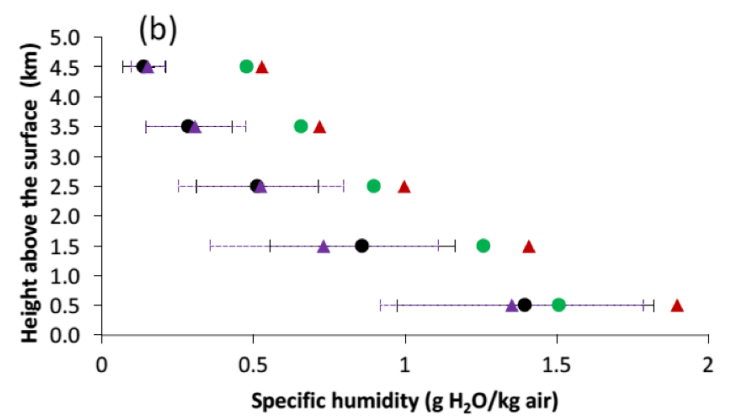

Figure 7. Comparisons of vertical profiles of (a) $\mathrm{O}_{3}$ and (b) specific humidity between GEOS-Chem simulations and ozonesondes in June and July 2008, respectively, averaged over $1 \mathrm{~km}$ altitude bins. Black and green solid circles represent observations and simulations in June 2008, while purple and red triangles denote observations and simulations for July 2008. Solid and dashed horizontal error bars represent observational standard deviations for June and July, respectively.

launched at Summit for the months of June and July 2008 and compared those data with model control runs. Ozonesondes were launched intensively during these 2 months (a total of 19 times). As shown in Fig. 7, compared with observations the model-simulated $\mathrm{O}_{3}$ mixing ratios averaged over 0 $5 \mathrm{~km}$ above ground level were underestimated by 3 and $9 \%$ in June and July 2008 (Fig. 7a). However, specific humidity in GEOS- 5 was overestimated by 50 and $81 \%$ (Fig. 7b), respectively. Ozonesonde data showed that Summit frequently encountered high $\mathrm{O}_{3}$ and low water vapor events (e.g., 911 July 2008), which were likely of upper tropospheric or stratospheric origin (Helmig et al., 2007), but these were not captured by the model, which implied that GEOS-Chem possibly underestimated STE for $\mathrm{O}_{3}$ over Summit. This is consistent with the study by Choi et al. (2017), which found low bias with model-simulated $\mathrm{O}_{3}$ mixing ratios for the upper troposphere of the high-latitude Northern Hemisphere compared with ozonesonde data and attributed the low bias to an underestimated STE in the model.

Misrepresentation of boundary layer height is another factor that could lead to model-data discrepancy in $\mathrm{O}_{3}$ mixing ratios. The mean springtime afternoon (12:00-14:00 LT, local time) boundary layer height in the model at Summit for the year 2009 was $160 \mathrm{~m}$, which agreed reasonably well with inferred boundary layer heights from vertical balloon soundings (Helmig et al., 2002). Therefore, it is unlikely that model uncertainties in boundary layer height representation in springtime cause the low bias of $\mathrm{O}_{3}$ mixing ratios between the model and observations.

\section{Conclusions}

We combined model simulations with 2-year (July 2008June 2010) ground-based measurements at Summit, Greenland to investigate the abundance and seasonal variations of surface $\mathrm{O}_{3}$ and related species in the Arctic. In general, the GEOS-Chem model was capable of reproducing the seasonal cycles of $\mathrm{NO}_{x}, \mathrm{PAN}, \mathrm{C}_{2} \mathrm{H}_{6}, \mathrm{C}_{3} \mathrm{H}_{8}, \mathrm{CO}$, and $\mathrm{O}_{3}$. However, some major discrepancies between the model and observations, especially for $\mathrm{NO}_{x}, \mathrm{PAN}, \mathrm{C}_{2} \mathrm{H}_{6}$, and $\mathrm{O}_{3}$, were identified.

There were significant differences between modelsimulated $\mathrm{NO}_{x}$ mixing ratios and observations for the spring and winter seasons. The model underestimated $\mathrm{NO}_{x}$ mixing ratios by approximately $50 \%$ during late spring to early summer, which was likely due to the missing $\mathrm{NO}_{x}$ emissions from nitrate photolysis in the snowpack. At the same time, the model overestimated $\mathrm{NO}_{x}$ mixing ratios by more than a factor of 2 in wintertime. Model simulations indicated episodic but frequent transport events from Europe in wintertime, leading to $\mathrm{NO}_{x}$ spikes reaching 15 times typical $\mathrm{NO}_{x}$ mixing ratios at Summit; these large $\mathrm{NO}_{x}$ spikes were not seen in the observations. We carried out multiple sensitivity model studies but were still unable to fully reconcile this discrepancy.

The model successfully captured the seasonal cycles and the spring maximum PAN mixing ratios, although it underestimated PAN by over $30 \%$ during late spring and early summer. Model sensitivity studies revealed that this discrepancy could be largely resolved by accounting for PAN emissions from snowpack.

For $\mathrm{C}_{3} \mathrm{H}_{8}$ and $\mathrm{CO}$, model simulations agreed well overall with the surface measurements. However, the model tended to systematically overestimate surface $\mathrm{C}_{2} \mathrm{H}_{6}$ mixing ratios by $\sim 20 \%$ on annual average compared with observations. This may be explained by the fact that annual emission budgets of $\mathrm{C}_{2} \mathrm{H}_{6}$ over the US and Asia from the X08 emission inventory were higher than those from NEI11 and MIX by over $40 \%$. By replacing X08 over the US with NEI11 for $\mathrm{C}_{2} \mathrm{H}_{6}$ and scaling up MIX by $20 \%$, the model-observation bias can be resolved, resulting in an annual mean bias of less than $1 \%$. However, care must be taken in interpreting this result because we did not take into account other factors that might influence the discrepancy in surface $\mathrm{C}_{2} \mathrm{H}_{6}$ mixing ratios at Summit between the model and observations, such as the $\mathrm{C}_{2} \mathrm{H}_{6}$ chemistry with chlorine.

GEOS-Chem was able to reproduce the seasonal variation in surface $\mathrm{O}_{3}$ at Summit but persistently underestimated $\mathrm{O}_{3}$ mixing ratios by $\sim 13 \%(\sim 6.5 \mathrm{ppbv})$ from April to July. 
This low bias was likely caused by a combination of misrepresentations, including the missing snowpack emissions of $\mathrm{NO}_{x}$ and HONO, an inaccurate representation of Summit's elevation with a too-coarse model resolution, and the underestimated STE.

All the results presented above reveal the importance of local snowpack emissions in regulating the atmospheric composition and chemistry over the Arctic. Improvements in global CTMs could likely be achieved by coupling snowpack emissions of reactive gases and photochemistry modules in order to better simulate $\mathrm{O}_{3}$ precursors and $\mathrm{O}_{3}$ over snow and ice (Zatko et al., 2016). Moreover, this study also demonstrates that anthropogenic emissions from the midlatitudes play an important role in affecting the Arctic atmosphere.

Data availability. Data used in this study can be provided upon request to the corresponding authors, Yaoxian Huang (yaoxianh@mtu.edu) and Shiliang Wu (slwu@mtu.edu).

\section{The Supplement related to this article is available online at https://doi.org/10.5194/acp-17-14661-2017- supplement.}

Competing interests. The authors declare that they have no conflict of interest.

Acknowledgements. This research was funded by US EPA grant 83518901. The findings are solely the responsibility of the grantee and do not necessarily represent the official views of the US EPA. Further, the US EPA does not endorse the purchase of any commercial products or services mentioned in the publication. Superior, a high-performance computing cluster at Michigan Technological University, was used to obtain the results presented in this publication. Louisa J. Kramer, Detlev Helmig, and on behalf of the late Richard E. Honrath thank NASA (grant NNX07AR26G) for supporting the measurements at Summit. Shiliang Wu acknowledges the sabbatical fellowship from the Ocean University of China. Detlev Helmig acknowledges support from the National Science Foundation under grant NSF AON 1108391. We also thank NOAA ESRL for providing the observational dataset of $\mathrm{O}_{3}$ and CO. Technical support from Melissa Sulprizio and Christoph Keller is also acknowledged.

Edited by: Jason West

Reviewed by: Hongyu Liu and one anonymous referee

\section{References}

Alvarado, M. J., Logan, J. A., Mao, J., Apel, E., Riemer, D., Blake, D., Cohen, R. C., Min, K.-E., Perring, A. E., Browne, E. C., Wooldridge, P. J., Diskin, G. S., Sachse, G. W., Fuelberg, H., Sessions, W. R., Harrigan, D. L., Huey, G., Liao, J.,
Case-Hanks, A., Jimenez, J. L., Cubison, M. J., Vay, S. A., Weinheimer, A. J., Knapp, D. J., Montzka, D. D., Flocke, F. M., Pollack, I. B., Wennberg, P. O., Kurten, A., Crounse, J., Clair, J. M. St., Wisthaler, A., Mikoviny, T., Yantosca, R. M., Carouge, C. C., and Le Sager, P.: Nitrogen oxides and PAN in plumes from boreal fires during ARCTAS-B and their impact on ozone: an integrated analysis of aircraft and satellite observations, Atmos. Chem. Phys., 10, 9739-9760, https://doi.org/10.5194/acp10-9739-2010, 2010.

Arnold, S. R., Emmons, L. K., Monks, S. A., Law, K. S., Ridley, D. A., Turquety, S., Tilmes, S., Thomas, J. L., Bouarar, I., Flemming, J., Huijnen, V., Mao, J., Duncan, B. N., Steenrod, S., Yoshida, Y., Langner, J., and Long, Y.: Biomass burning influence on high-latitude tropospheric ozone and reactive nitrogen in summer 2008: a multi-model analysis based on POLMIP simulations, Atmos. Chem. Phys., 15, 6047-6068, https://doi.org/10.5194/acp-15-6047-2015, 2015.

Bey, I., Jacob, D. J., Yantosca, R. M., Logan, J. A., Field, B. D., Fiore, A. M., Li, Q., Liu, H., Mickley L. J., and Schultz, M. G.: Global modeling of tropospheric chemistry with assimilated meteorology: Model description and evaluation, J. Geophys. Res.Atmos., 106, 23073-23095, 2001.

Chen, D., Wang, Y., McElroy, M. B., He, K., Yantosca, R. M., and Le Sager, P.: Regional CO pollution and export in China simulated by the high-resolution nested-grid GEOS-Chem model, Atmos. Chem. Phys., 9, 3825-3839, https://doi.org/10.5194/acp-93825-2009, 2009.

Choi, H.-D., Liu, H., Crawford, J. H., Considine, D. B., Allen, D. J., Duncan, B. N., Horowitz, L. W., Rodriguez, J. M., Strahan, S. E., Zhang, L., Liu, X., Damon, M. R., and Steenrod, S. D.: Global $\mathrm{O}_{3}-\mathrm{CO}$ correlations in a chemistry and transport model during July-August: evaluation with TES satellite observations and sensitivity to input meteorological data and emissions, Atmos. Chem. Phys., 17, 8429-8-452, https://doi.org/10.5194/acp17-8429-2017, 2017.

Christian, K. E., Brune, W. H., and Mao, J.: Global sensitivity analysis of the GEOS-Chem chemical transport model: ozone and hydrogen oxides during ARCTAS (2008), Atmos. Chem. Phys., 17, 3769-3784, https://doi.org/10.5194/acp-17-3769-2017, 2017.

Crawford, J. H., Davis, D. D., Chen, G., Buhr, M., Oltmans, S., Weller, R., Mauldin, L., Eisele, F., Shetter, R., Lefer, B., Arimoto, R., and Hogan, A.: Evidence for photochemical production of ozone at the South Pole surface, Geophys. Res. Lett., 28, 3641-3644, 2001.

Dibb, J. E., Arsenault, M., Peterson, M. C., and Honrath, R. E.: Fast nitrogen oxide photochemistry in Summit, Greenland snow, Atmos. Environ., 36, 2501-2511, 2002.

Dibb, J. E., Whitlow, S. I., and Arsenault, M.: Seasonal variations in the soluble ion content of snow at Summit. Greenland: Constraints from three years of daily surface snow samples, Atmos. Environ., 41, 5007-5019, https://doi.org/10.1016/j.atmosenv.2006.12.010, 2007.

Fiore, A. M., Jacob, D. J., Field, B. D., Streets, D. G., Fernandes, S. D., and Jang, C.: Linking ozone pollution and climate change: The case for controlling methane, Geophys. Res. Lett., 29, 1919, https://doi.org/10.1029/2002GL015601, 2002.

Fischer, E. V., Jacob, D. J., Yantosca, R. M., Sulprizio, M. P., Millet, D. B., Mao, J., Paulot, F., Singh, H. B., Roiger, A., Ries, L., Talbot, R. W., Dzepina, K., and Pandey Deolal, 
S.: Atmospheric peroxyacetyl nitrate (PAN): a global budget and source attribution, Atmos. Chem. Phys., 14, 2679-2698, https://doi.org/10.5194/acp-14-2679-2014, 2014.

Ford, K. M., Shepson, P. B., Bertman, S. B., Honrath, R. E., Peterson, M., Dibb, J. E., and Bottenheim, J. W.: Studies of peroxyacetyl nitrate (PAN) and its interaction with the snowpack at Summit, Greenland, J. Geophys. Res., 107, 4102, https://doi.org/10.1029/2001JD000547, 2002.

Franco, B., Bader, W., Toon, G., Bray, C., Perrin, A., Fischer, E., Sudo, K., Boone, C., Bovy, B., Lejeune, B., Servais, C., and Mahieu, E.: Retrieval of ethane from ground-based FTIR solar spectra using improved spectroscopy: Recent burden increase above Jungfraujoch, J. Quant. Spectrosc. Ra., 160, 36-49, https://doi.org/10.1016/j.jqsrt.2015.03.017, 2015.

Franco, B., Mahieu, E., Emmons, L. K., Tzompa-Sosa, Z. A., Fischer, E. V., Sudo, K., Bovy, B., Conway, S., Griffin, D., Hannigan, J. W., Strong, K., and Walker, K. A.: Evaluating ethane and methane emissions associated with the development of oil and natural gas extraction in North America, Environ. Res. Lett., 11, 044010, https://doi.org/10.1088/1748-9326/11/4/044010, 2016.

Frey, M. M., Brough, N., France, J. L., Anderson, P. S., Traulle, O., King, M. D., Jones, A. E., Wolff, E. W., and Savarino, J.: The diurnal variability of atmospheric nitrogen oxides (NO and $\mathrm{NO}_{2}$ ) above the Antarctic Plateau driven by atmospheric stability and snow emissions, Atmos. Chem. Phys., 13, 3045-3062, https://doi.org/10.5194/acp-13-3045-2013, 2013.

Gerbig, C., Schmitgen, S., Kley, D., Volz-Thomas, A., Dewey, K., and Haaks, D.: An improved fast-response vacuum-UV resonance fluorescence CO instrument, J. Geophys. Res., 104, 16991704, 1999.

Giglio, L., Randerson, J. T., and van der Werf, G. R.: Analysis of daily, monthly, and annual burned area using the fourthgeneration global fire emissions database (GFED4), J. Geophys. Res.-Biogeo., 118, 317-328, https://doi.org/10.1002/jgrg.20042, 2013.

Grannas, A. M., Jones, A. E., Dibb, J., Ammann, M., Anastasio, C., Beine, H. J., Bergin, M., Bottenheim, J., Boxe, C. S., Carver, G., Chen, G., Crawford, J. H., Dominé, F., Frey, M. M., Guzmàn, M. I., Heard, D. E., Helmig, D., Hoffmann, M. R., Honrath, R. E., Huey, L. G., Hutterli, M., Jacobi, H. W., Klàn, P., Lefer, B., McConnell, J., Plane, J., Sander, R., Savarino, J., Shepson, P. B., Simpson, W. R., Sodeau, J. R., von Glasow, R., Weller, R., Wolff, E. W., and Zhu, T.: An overview of snow photochemistry: evidence, mechanisms and impacts, Atmos. Chem. Phys., 7, 43294373, https://doi.org/10.5194/acp-7-4329-2007, 2007.

Guenther, A., Karl, T., Harley, P., Wiedinmyer, C., Palmer, P. I., and Geron, C.: Estimates of global terrestrial isoprene emissions using MEGAN (Model of Emissions of Gases and Aerosols from Nature), Atmos. Chem. Phys., 6, 3181-3210, https://doi.org/10.5194/acp-6-3181-2006, 2006.

Hausmann, P., Sussmann, R., and Smale, D.: Contribution of oil and natural gas production to renewed increase in atmospheric methane (2007-2014): top-down estimate from ethane and methane column observations, Atmos. Chem. Phys., 16, 3227-3244, https://doi.org/10.5194/acp-16-3227-2016, 2016.

Helmig, D., Boulter, J., David, D., Birks, J. W., Cullen, N. J., Steffen, K., Johnson, B. J., and Oltmans, S. J.: Ozone and meteorological boundary-layer conditions at Summit, Green- land, during 3-21 June 2000, Atmos. Environ., 36, 2595-2608, https://doi.org/10.1016/S1352-2310(02)00129-2, 2002.

Helmig, D., Oltmans, S. J., Morse, T. O., and Dibb, J. E.: What is causing high ozone at Summit, Greenland?, Atmos. Environ., 41, 5031-5043, https://doi.org/10.1016/j.atmosenv.2006.05.084, 2007.

Helmig, D., Johnson, B., Oltmans, S. J., Neff, W., Eisele, F., and Davis, D. D.: Elevated ozone in the boundary-layer at South Pole, Atmos. Environ., 42, 2788-2803, 2008.

Helmig, D., Petrenko, V., Martinerie, P., Witrant, E., Röckmann, T., Zuiderweg, A., Holzinger, R., Hueber, J., Thompson, C., White, J. W. C., Sturges, W., Baker, A., Blunier, T., Etheridge, D., Rubino, M., and Tans, P.: Reconstruction of Northern Hemisphere 1950-2010 atmospheric non-methane hydrocarbons, Atmos. Chem. Phys., 14, 1463-1483, https://doi.org/10.5194/acp14-1463-2014, 2014a.

Helmig, D., Stephens, C., Caramore, J., and Hueber, J.: Seasonal behavior of non-methane hydrocarbons in the firn air at Summit, Greenland, Atmos. Environ., 85, 234-246, https://doi.org/10.1016/j.atmosenv.2013.11.021, 2014b.

Helmig, D., Rossabi, S., Hueber, J., Tans, P., Montzka, S. A., Masarie, K., Thoning, K., Plass-Duelmer, C., Claude, A., Carpenter, L. J., Lewis, A. C., Punjabi, S., Reimann, S., Vollmer, M. K., Steinbrecher, R., Hannigan, J. W., Emmons, L. K., Mahieu, E., Franco, B., Smale, D., and Pozzer, A.: Reversal of global atmospheric ethane and propane trends largely due to US oil and natural gas production, Nat. Geosci., 9, 490-495, https://doi.org/10.1038/ngeo2721, 2016.

Hickman, J. E., Huang, Y., Wu, S., Diru, W., Groffman, P. M., Tully, K. L., and Palm, C. A.: Nonlinear response of nitric oxide fluxes to fertilizer inputs and the impacts of agricultural intensification on tropospheric ozone pollution in Kenya, Glob. Change Biol., 23, 3193-3204, https://doi.org/10.1111/gcb.13644, 2017.

Hollaway, M. J., Arnold, S. R., Challinor, A. J., and Emberson, L. D.: Intercontinental trans-boundary contributions to ozone-induced crop yield losses in the Northern Hemisphere, Biogeosciences, 9, 271-292, https://doi.org/10.5194/bg-9-2712012, 2012.

Honrath, R. E., Peterson, M. C., Guo, S., Dibb, J. E., Shepson, P. B., and Campbell, B.: Evidence of $\mathrm{NO}_{x}$ production within or upon ice particles in the Greenland snowpack, Geophys. Res. Lett., 26, 695-698, 1999.

Honrath, R. E., Guo, S., Peterson, M. C., Dziobak, M. P., Dibb, J. E., and Arsenault, M. A.: Photochemical production of gas phase $\mathrm{NO}_{x}$ from ice crystal $\mathrm{NO}_{3}^{-}$, J. Geophys. Res., 105, $24183-$ 24190, 2000a.

Honrath, R. E., Peterson, M. C., Dziobak, M. P., Dibb, J. E., Arsenault, M. A., and Green, S. A.: Release of $\mathrm{NO}_{x}$ from Sunlightirradiated Midlatitude Snow, Geophys. Res. Lett., 27, 22372240, 2000b

Honrath, R. E., Lu, Y., Peterson, M. C., Dibb, J. E., Arsenault, M. A., Cullen, N. J., and Steffen, K.: Vertical fluxes of $\mathrm{NO}_{x}$, $\mathrm{HONO}$, and $\mathrm{HNO}_{3}$ above the snowpack at Summit, Greenland, Atmos. Environ., 36, 2629-2640, https://doi.org/10.1016/S13522310(02)00132-2, 2002.

Huang, Y., Wu, S., Dubey, M. K., and French, N. H. F.: Impact of aging mechanism on model simulated carbonaceous aerosols, Atmos. Chem. Phys., 13, 6329-6343, https://doi.org/10.5194/acp13-6329-2013, 2013. 
Hudman, R. C., Murray, L. T., Jacob, D. J., Turquety, S., Wu, S., Millet, D. B., Avery, M., Goldstein, A. H., and Holloway, J.: North American influence on tropospheric ozone and the effects of recent emission reductions: Constraints from ICARTT observations, J. Geophys. Res., 114, D07302, https://doi.org/10.1029/2008JD010126, 2009.

Hudman, R. C., Moore, N. E., Mebust, A. K., Martin, R. V., Russell, A. R., Valin, L. C., and Cohen, R. C.: Steps towards a mechanistic model of global soil nitric oxide emissions: implementation and space based-constraints, Atmos. Chem. Phys., 12, 7779-7795, https://doi.org/10.5194/acp-12-7779-2012, 2012.

Jacob, D. J., Wofsy, S. C., Bakwin, P. S., Fan, S.-M., Harriss, R. C., Talbot, R. W., Bradshaw, J. D., Sandholm, S. T., Singh, H. B., Browell, E. V., Gregory, G. L., Sachse, G. W., Shipham, M. C., Blake, D. R., and Fitzjarrald, D. R.: Summertime photochemistry of the troposphere at high northern latitudes, J. Geophys. Res., 97, 16421-16431, https://doi.org/10.1029/91JD01968, 1992.

Jang, J.-C., Jeffries, H., Byun, D., and Pleim, J.: Sensitivity of ozone to model grid resolution - I. Application of high resolution regional acid deposition model, Atmos. Environ., 29, 3085-3100, https://doi.org/10.1016/1352-2310(95)00118-I, 1995.

Johnson, M.S., Meskhidze, N., Solmon, F., Gasso, S., Chuang, P. Y., Gaiero, D. M., Yantosca, R. M., Wu, S., Wang, X., and Carouge, C.: Modeling Dust and Soluble Iron Deposition to the South Atlantic Ocean, J. Geophys. Res., 115, D15202, https://doi.org/10.1029/2009JD013311, 2010.

Kramer, L. J., Helmig, D., Burkhart, J. F., Stohl, A., Oltmans, S., and Honrath, R. E.: Seasonal variability of atmospheric nitrogen oxides and non-methane hydrocarbons at the GEOSummit station, Greenland, Atmos. Chem. Phys., 15, 6827-6849, https://doi.org/10.5194/acp-15-6827-2015, 2015.

Kuhns, H., Knipping, E. M., and Vukovich, J. M.: Development of a United States-Mexico emissions inventory for the Big Bend Regional Aerosol and Visibility Observational (BRAVO) Study, J. Air Waste Manage., 55, 677-692, 2005.

Kumar, A., Wu, S., Weise, M. F., Honrath, R., Owen, R. C., Helmig, D., Kramer, L., Val Martin, M., and Li, Q.: Freetroposphere ozone and carbon monoxide over the North Atlantic for 2001-2011, Atmos. Chem. Phys., 13, 12537-12547, https://doi.org/10.5194/acp-13-12537-2013, 2013.

Legrand, M., Preunkert, S., Frey, M., Bartels-Rausch, Th., Kukui, A., King, M. D., Savarino, J., Kerbrat, M., and Jourdain, B.: Large mixing ratios of atmospheric nitrous acid (HONO) at Concordia (East Antarctic Plateau) in summer: a strong source from surface snow?, Atmos. Chem. Phys., 14, 9963-9976, https://doi.org/10.5194/acp-14-9963-2014, 2014.

Li, M., Zhang, Q., Kurokawa, J.-I., Woo, J.-H., He, K., Lu, Z., Ohara, T., Song, Y., Streets, D. G., Carmichael, G. R., Cheng, Y., Hong, C., Huo, H., Jiang, X., Kang, S., Liu, F., Su, H., and Zheng, B.: MIX: a mosaic Asian anthropogenic emission inventory under the international collaboration framework of the MICS-Asia and HTAP, Atmos. Chem. Phys., 17, 935-963, https://doi.org/10.5194/acp-17-935-2017, 2017.

Liang, J. and Jacobson, M. Z.: Effects of subgrid segregation on ozone production efficiency in a chemical model, Atmos. Environ., 34, 2975-2982, https://doi.org/10.1016/S13522310(99)00520-8, 2000.

Liang, Q., Rodriguez, J. M., Douglass, A. R., Crawford, J. H., Olson, J. R., Apel, E., Bian, H., Blake, D. R., Brune, W., Chin, M.,
Colarco, P. R., da Silva, A., Diskin, G. S., Duncan, B. N., Huey, L. G., Knapp, D. J., Montzka, D. D., Nielsen, J. E., Pawson, S., Riemer, D. D., Weinheimer, A. J., and Wisthaler, A.: Reactive nitrogen, ozone and ozone production in the Arctic troposphere and the impact of stratosphere-troposphere exchange, Atmos. Chem. Phys., 11, 13181-13199, https://doi.org/10.5194/acp-11-131812011, 2011.

Liu, H. Y., Jacob, D. J., Bey, I., and Yantosca, R. M.: Constraints from pb-210 and $\mathrm{Be}-7$ on wet deposition and transport in a global three-dimensional chemical tracer model driven by assimilated meteorological fields, J. Geophys. Res.-Atmos., 106, 12109-12128, https://doi.org/10.1029/2000JD900839, 2001.

Martin, R. V., Jacob, D. J., Logan, J. A., Bey, I., Yantosca, R. M., Staudt, A. C., Li, Q., Fiore, A. M., Duncan, B. N., and Liu, H.: Interpretation of TOMS observations of tropical tropospheric ozone with a global model and in situ observations, J. Geophys. Res., 107, ACH4-1-ACH4-27, https://doi.org/10.1029/2001JD001480, 2002.

McClure-Begley, A., Petropavlovskikh, I., and Oltmans, S.: NOAA Global Monitoring Surface Ozone Network. 1973-2014. National Oceanic and Atmospheric Administration, Earth Systems Research Laboratory Global Monitoring Division, Boulder, CO, available at: https://doi.org/10.7289/V57P8WBF (last access: 23 April 2017), 2014.

McLinden, C. A., Olsen, S. C., Hannegan, B., Wild, O., Prather, M. J., and Sundet, J.: Stratospheric ozone in 3-D models: A simple chemistry and the cross-tropopause flux, J. Geophys. Res., 105, 14653-14665, https://doi.org/10.1029/2000JD900124, 2000.

Monks, S. A., Arnold, S. R., Emmons, L. K., Law, K. S., Turquety, S., Duncan, B. N., Flemming, J., Huijnen, V., Tilmes, S., Langner, J., Mao, J., Long, Y., Thomas, J. L., Steenrod, S. D., Raut, J. C., Wilson, C., Chipperfield, M. P., Diskin, G. S., Weinheimer, A., Schlager, H., and Ancellet, G.: Multi-model study of chemical and physical controls on transport of anthropogenic and biomass burning pollution to the Arctic, Atmos. Chem. Phys., 15, 3575-3603, https://doi.org/10.5194/acp-15-3575-2015, 2015.

Murray, K. A., Kramer, L. J., Doskey, P. V., Ganzeveld, L., Seok, B., Van Dam, B., and Helmig, D.: Dynamics of ozone and nitrogen oxides at Summit, Greenland. II. Simulating snowpack chemistry during a spring high ozone event with a 1-D process-scale model, Atmos. Environ., 117, 110-123, https://doi.org/10.1016/j.atmosenv.2015.07.004, 2015.

Murray, L. T., Jacob, D. J., Logan, J. A., Hudman, R. C., and Koshak, W. J.: Optimized regional and interannual variability of lightning in a global chemical transport constrained by LIS/OTD satellite data, J. Geophys. Res., 117, D20307, https://doi.org/10.1029/2012JD017934, 2012.

Novelli, P. C., Masarie, K. A., Lang, P. M., Hall, B. D., Myers, R. C., and Elkins, J. W.: Re-analysis of tropospheric CO trends: Effects of the 1997-1998 wild fires, J. Geophys. Res., 108, 4464, https://doi.org/10.1029/2002JD003031, 2003.

Park, R. J., Jacob, D. J., Field, B. D., Yantosca, R. M., and Chin, M.: Natural and transboundary pollution influences on sulfate-nitrate-ammonium aerosols in the United States: Implications for policy, J. Geophys. Res.-Atmos., 109, D15204, https://doi.org/10.1029/2003JD004473, 2004.

Petropavlovskikh, I. and Oltmans, S. J.: Tropospheric Ozone Measurements, 1973-2011, Version: 2012-07-10, NOAA, available 
at: ftp://aftp.cmdl.noaa.gov/data/ozwv/SurfaceOzone/ (last access: 15 February 2016), 2012.

Price, C. and Rind, D.: A simple lightning parameterization for calculating global lightning distributions, J. Geophys. Res., 97, 9919-9933, https://doi.org/10.1029/92JD00719,1992.

Ridley, B. A. and Grahek, F.: A small, low flow, high sensitivity reaction vessel for NO chemiluminescence detectors, Am. Meteorol. Soc., 7, 307-311, 1990.

Sauvage, B., Martin, R. V., van Donkelaar, A., Liu, X., Chance, K., Jaeglé, L., Palmer, P. I., Wu, S., and Fu, T.-M.: Remote sensed and in situ constraints on processes affecting tropical tropospheric ozone, Atmos. Chem. Phys., 7, 815-838, https://doi.org/10.5194/acp-7-815-2007, 2007.

Sherwen, T., Schmidt, J. A., Evans, M. J., Carpenter, L. J., Großmann, K., Eastham, S. D., Jacob, D. J., Dix, B., Koenig, T. K., Sinreich, R., Ortega, I., Volkamer, R., Saiz-Lopez, A., PradosRoman, C., Mahajan, A. S., and Ordóñez, C.: Global impacts of tropospheric halogens $(\mathrm{Cl}, \mathrm{Br}, \mathrm{I})$ on oxidants and composition in GEOS-Chem, Atmos. Chem. Phys., 16, 12239-12271, https://doi.org/10.5194/acp-16-12239-2016, 2016.

Shindell, D. T., Chin, M., Dentener, F., Doherty, R. M., Faluvegi, G., Fiore, A. M., Hess, P., Koch, D. M., MacKenzie, I. A., Sanderson, M. G., Schultz, M. G., Schulz, M., Stevenson, D. S., Teich, H., Textor, C., Wild, O., Bergmann, D. J., Bey, I., Bian, H., Cuvelier, C., Duncan, B. N., Folberth, G., Horowitz, L. W., Jonson, J., Kaminski, J. W., Marmer, E., Park, R., Pringle, K. J., Schroeder, S., Szopa, S., Takemura, T., Zeng, G., Keating, T. J., and Zuber, A.: A multi-model assessment of pollution transport to the Arctic, Atmos. Chem. Phys., 8, 5353-5372, https://doi.org/10.5194/acp-8-5353-2008, 2008.

Simon, H., Beck, L., Bhave, P. V., Divita, F., Hsu, Y., Luecken, D., Mobley, J. D., Pouliot, G. A., Reff, A., Sarwar, G., and Strum, M.: The development and uses of EPA's SPECIATE database, Atmos. Pollut. Res., 1, 196-206, https://doi.org/10.5094/apr.2010.026, 2010.

Simpson, I. J., Sulbaek Andersen, M. P., Meinardi, S., Bruhwiler, L., Blake, N. J., Helmig, D., Rowland, F. S. and Blake, D. R.: Long-term decline of global atmospheric ethane concentrations and implications for methane, Nature, 488, 490-494, https://doi.org/10.1038/nature11342, 2012.

Thomas, J. L., Stutz, J., Lefer, B., Huey, L. G., Toyota, K., Dibb, J. E., and von Glasow, R.: Modeling chemistry in and above snow at Summit, Greenland - Part 1: Model description and results, Atmos. Chem. Phys., 11, 4899-4914, https://doi.org/10.5194/acp11-4899-2011, 2011.

Thomas, J. L., Dibb, J. E., Huey, L. G., Liao, J., Tanner, D., Lefer, B., von Glasow, R., and Stutz, J.: Modeling chemistry in and above snow at Summit, Greenland - Part 2: Impact of snowpack chemistry on the oxidation capacity of the boundary layer, Atmos. Chem. Phys., 12, 6537-6554, https://doi.org/10.5194/acp12-6537-2012, 2012.

Tzompa-Sosa, Z. A., Mahieu, E., Franco, B., Keller, C. A., Turner, A. J., Helmig, D., Fried, A., Richter, D., Weibring, P., Walega, J., Yacovitch, T. I., Herndon, S. C., Blake, D. R., Hase, F., Hannigan, J. W., Conway, S., Strong, K., Schneider, M., and Fischer, E. V.: Revisiting global fossil fuel and biofuel emissions of ethane, J. Geophys. Res.-Atmos., 122, 2493-2512, https://doi.org/10.1002/2016JD025767, 2017.
Unger, N., Shindell, D. T., Koch, D. M., and Streets, D. G.: Cross influences of ozone and sulfate precursor emissions changes on air quality and climate, P. Natl. Acad. Sci. USA, 103, 4377-4380, https://doi.org/10.1073/pnas.0508769103, 2006.

van het Bolscher, M., Pereira, J., Spesso, A., Dalsoren, S., van Noije, T., and Szopa, S.: REanalysis of the TROpospheric chemical composition over the past 40 years: A long-term global modeling study of tropospheric chemistry, Max Plank Inst. For Meteorology, Hamburg, Germany, 77, 2008.

Van Dam, B., Helmig, D., Toro, C., Doskey, P., Kramer, L., Murray, K., Ganzeveld, L., and Seok, B.: Dynamics of ozone and nitrogen oxides at Summit, Greenland: I. Multi-year observations in the snowpack, Atmos. Environ., 123, 268-284, https://doi.org/10.1016/j.atmosenv.2015.09.060, 2015.

Walker, T. W., Jones, D. B. A., Parrington, M., Henze, D. K., Murray, L. T., Bottenheim, J. W., Anlauf, K., Worden, J. R., Bowman, K. W., Shim, C., Singh, K., Kopacz, M., Tarasick, D. W., Davies, J., von der Gathen, P., Thompson, A. M., and Carouge, C. C.: Impacts of midlatitude precursor emissions and local photochemistry on ozone abundances in the Arctic, J. Geophys. Res., 117, D01305, https://doi.org/10.1029/2011JD016370, 2012.

Wang, Y. H., Jacob, D. J., and Logan, J. A.: Global simulation of tropospheric $\mathrm{O}_{3}-\mathrm{NO}_{x}$-hydrocarbon chemistry 1. Model formulation, J. Geophys. Res.-Atmos., 103, 10713-10725, https://doi.org/10.1029/98JD00158, 1998.

Wang, Y. X., McElroy, M. B., Jacob, D. J., and Yantosca, R. M.: A nested grid formulation for chemical transport over Asia: Applications to CO, J. Geophys. Res., 109, D22307, https://doi.org/10.1029/2004JD005237, 2004.

Wesely, M. L.: Parameterization of surface resistances to gaseous dry deposition in regional-scale numerical-models, Atmos. Environ., 23, 1293-1304, https://doi.org/10.1016/00046981(89)90153-4, 1989.

Wespes, C., Emmons, L., Edwards, D. P., Hannigan, J., Hurtmans, D., Saunois, M., Coheur, P.-F., Clerbaux, C., Coffey, M. T., Batchelor, R. L., Lindenmaier, R., Strong, K., Weinheimer, A. J., Nowak, J. B., Ryerson, T. B., Crounse, J. D., and Wennberg, P. O.: Analysis of ozone and nitric acid in spring and summer Arctic pollution using aircraft, ground-based, satellite observations and MOZART-4 model: source attribution and partitioning, Atmos. Chem. Phys., 12, 237-259, https://doi.org/10.5194/acp12-237-2012, 2012.

Wu, S., Mickley, L. J., Jacob, D. J., Logan, J. A., Yantosca, R. M., and Rind, D.: Why are there large differences between models in global budgets of tropospheric ozone?, J. Geophys. Res., 112, D05302, https://doi.org/10.1029/2006JD007801, 2007.

Xiao, Y., Logan, J. A., Jacob, D. J., Hudman, R. C., Yantosca, R., and Blake, D. R.: The global budget of ethane and regional constrainsts on U.S. sources, J. Geophys. Res., 113, D21306, https://doi.org/10.1029/2007JD009415, 2008.

Yang, J., Honrath, R. E., Peterson, M. C., Dibb, J. E., Sumner, A. L., Shepson, P. B., Frey, M., Jacobi, H.-W., Swanson, A., and Blake, N.: Impacts of snowpack emissions on deduced levels of $\mathrm{OH}$ and peroxy radicals at Summit, Greenland, Atmos. Environ. 36, 2523-2534, https://doi.org/10.1016/S1352-2310(02)00128$0,2002$.

Yevich, R. and Logan, J. A.: An assesment of biofuel use and burning of agricultural waste in the de- 
veloping world, Global Biogeochem. Cy., 17, 1095, https://doi.org/10.1029/2002GB001952, 2003.

Yu, K., Jacob, D. J., Fisher, J. A., Kim, P. S., Marais, E. A., Miller, C. C., Travis, K. R., Zhu, L., Yantosca, R. M., Sulprizio, M. P., Cohen, R. C., Dibb, J. E., Fried, A., Mikoviny, T., Ryerson, T. B., Wennberg, P. O., and Wisthaler, A.: Sensitivity to grid resolution in the ability of a chemical transport model to simulate observed oxidant chemistry under high-isoprene conditions, Atmos. Chem. Phys., 16, 4369-4378, https://doi.org/10.5194/acp16-4369-2016, 2016.

Zatko, M., Geng, L., Alexander, B., Sofen, E., and Klein, K.: The impact of snow nitrate photolysis on boundary layer chemistry and the recycling and redistribution of reactive nitrogen across Antarctica and Greenland in a global chemical transport model, Atmos. Chem. Phys., 16, 2819-2842, https://doi.org/10.5194/acp-16-2819-2016, 2016.
Zhang, H., Wu, S., Huang, Y., and Wang, Y.: Effects of stratospheric ozone recovery on photochemistry and ozone air quality in the troposphere, Atmos. Chem. Phys., 14, 4079-4086, https://doi.org/10.5194/acp-14-4079-2014, 2014.

Zhou, X., Beine, H. J., Honrath, R. E., Fuentes, J., Simpson, W., Shepson, P. B., and Bottenheim, J. W.: snowpack photochemical production of HONO: a major source of $\mathrm{OH}$ in the Arctic boundary layer in springtime, Geophys. Res. Lett., 28, 40874090, 2001. 